\title{
Acquisition of vacated home ranges by tigers
}

\author{
Randeep Singh $^{1,2, *}$, Puneet Pandey ${ }^{1,2}$, Qamar Qureshi ${ }^{1}$, \\ Kalyanasundaram Sankar ${ }^{1,3}$, Paul R. Krausman ${ }^{4}$ and Surendra Prakash Goyal ${ }^{1}$ \\ ${ }^{1}$ Wildlife Institute of India, Post Box \# 18, Dehradun 248 001, India \\ ${ }^{2}$ Amity Institute of Forestry and Wildlife, Amity University, Sector-125, Noida 201 303, India \\ ${ }^{3}$ Salim Ali Centre for Ornithology and Natural History, Coimbatore 641 108, India \\ ${ }^{4}$ School of Natural Resources and the Environment, University of Arizona, Tucson, Arizona 85721, USA
}

\begin{abstract}
Understanding the social organization and acquisition of potential home ranges in solitary polygamous mammals is important for their management and conservation. However, such information requires a continuous long-term study. Therefore, limited information is available for mammals from South Asia. We studied the western most distributed Bengal tiger (Panthera tigris) population of Ranthambhore Tiger Reserve (RTR), Rajasthan, India, intensively during 2005-2011 using direct observation and intensive camera trapping-based methods. We examined how the home ranges of deceased tigers would be filled. Nine home ranges of tigers were vacated (two males and seven females) because of death, translocation, emigration and dispersal. Vacated female home ranges were filled by neighbouring tigers; $57 \%$ of neighbouring females were related to each other and after females vacated their ranges, their daughters acquired these home ranges. Mother tigers shared their home ranges with their daughters to increase the reproductive success of the latter. The home range of adult male tiger (TM-02) was estimated to be 73 sq. km using camera traps. Vacated male home ranges were filled by four transient individuals that were not related to each other. These data help understand the social organization and land tenure system of tigers in semi-arid habitats of India.
\end{abstract}

Keywords: Camera trap, home range acquisition, land tenure system, Panthera tigris, social organization.

IN polygamous mammals, territorial behaviour influences social organization, distribution, population structure and dynamics $^{1,2}$. Social organization, however, facilitates the species to exploit resources, in territory acquisition and to increase their reproductive opportunities ${ }^{3}$. Tigers (Panthera tigris) are solitary carnivores with a polygamous mating system ${ }^{4}$ and are listed as an endangered species by the International Union for Conservation of Nature $(\mathrm{IUCN})^{5,6}$. Adult male tigers usually have a body weight $>200 \mathrm{~kg}$ and large territories (>100 sq. km), while female tigers have an average body weight of $<150 \mathrm{~kg}$ and smaller ranges $(10-30 \mathrm{sq} . \mathrm{km})^{7}$ than males. Sub-adult

*For correspondence. (e-mail: randeep04@rediffmail.com) male tigers generally start dispersing between 19 and 28 months, to longer distances from their natal areas ${ }^{8,9}$. Females establish territories near their mothers' home ranges; dispersal of female tigers is rarely documented, and is considered to be rare $^{8}$. In the land tenure system, resident animals are confronted directly and indirectly by other conspecifics through territoriality and temporal avoidance through chemical clues that regulate their density $^{10,11}$. Resident male tigers have intra-sexual territories (male-male competition) and defend their territories assertively influenced by resource competition; but they allow multiple females to use their home ranges ${ }^{5,12}$. Subadults have been killed by adult animals because of territorial disputes in tiger $^{13}$, lion (Panthera leo) ${ }^{14}$, brown bear (Ursus arctos) $)^{15}$ and jaguar (Panthera onca) ${ }^{16}$ populations. Thus territory acquisition is important, especially for sub-adult or transient tigers in core habitats where competition is high. Natural or anthropogenic death of resident individuals during dispersal may create vacant home ranges, which can be filled by transient individuals or neighbouring residents ${ }^{4,17,18}$. Therefore it is important to understand the social organization and acquisition of vacant home ranges in animal ecology, and landscape level conservation and management ${ }^{19-21}$. We studied the western-most distributed, small and isolated population of tigers in the dry, tropical habitat of Ranthambhore Tiger Reserve (RTR), Sawai Madhopur district, Rajasthan India. The tiger population in the landscape is composed of $<50$ individuals ${ }^{22}$. However there is 344 sq. $\mathrm{km}$ of potential habitat for tigers in $\mathrm{RTR}^{22}$, which could support additional tigers. In the present study, we examined how the home ranges of deceased male and female tigers would be filled by transient or neighbouring resident tigers. These data help understand the social organization and land tenure system of tigers in semi-arid habitats of India.

\section{Study area}

The study was conducted in a semi-arid landscape in RTR, which is situated at the junction of the Aravalli and Vindhya hill ranges. The total area of RTR is 1394 sq. $\mathrm{km}$ and it consists of two management units: a 


\section{RESEARCH ARTICLES}

core area which includes the Ranthambhore National Park (RNP; 392 sq. km) and a buffer area, including the Sawai Mann Singh (SWS) wildlife sanctuary (WLS) (330 sq. km) and Kailadevi (KD) WLS (672 sq. km; Figure 1). In RTR, 36 tigers were reported during 2010 (ref. 23), among which 27 were reported from $\mathrm{RNP}^{24}$. The vegetation of RTR corresponds to that of northern tropical dry deciduous forests and northern tropical thorn forest $^{25}$. The region receives an average annual rainfall of $800 \mathrm{~mm}$, and temperatures can be low as $2^{\circ} \mathrm{C}$ in January and as high as $47^{\circ} \mathrm{C}$ in May. The vegetation of RTR is representative of a typical, dry, deciduous dhok (Anogeissus pendula) forest. Apart from dhok, the other species commonly found are kadaya (Sterculia urens), salai (Boswellia serrata), raunj (Acacia leucophloea), amaltas (Cassia fistula), palash (Butea monosperma), tendu (Diospyros melanoxylon), gurjan (Lannea coromandelica) and jamun (Syzigium cumini). Ranthambhore is characterized by a subtropical dry climate with four distinct seasons: winter (December-February), summer (MarchJune), monsoon (July-September) and post-monsoon (October-November). Large predators include tiger, leopard (Panthera pardus), sloth bear (Melursus ursinus) and striped hyaena (Hyaena hyaena). The RTR supports five species of wild ungulates, including the chital (Axis axis), sambar (Rusa unicolor), nilgai (Boselaphus tragocamelus), chinkara (Gazella gazelle) and wild boar (Sus scrofa).

\section{Methods}

\section{Monitoring tigers}

We monitored the tiger population in RTR through camera traps ( 1 camera trap/sq. $\mathrm{km}$ ) in the core area from April 2005 to June 2011 (Supplementary Figure 1). We

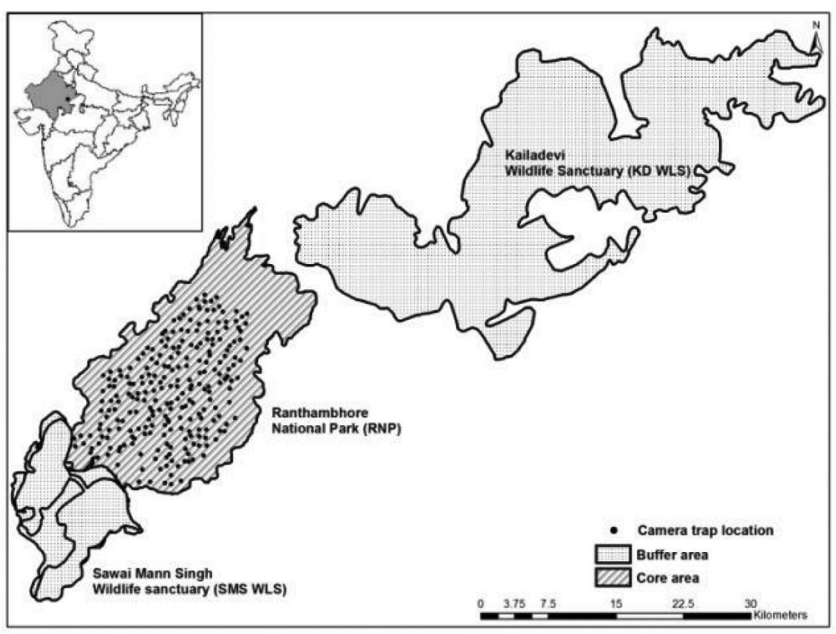

Figure 1. Study area map of Ranthambhore Tiger Reserve along with camera trapping location used for sampling during 2005-11. established a database of 647 photo-captures of 22 female tigers in RTR from April 2005 to June 2011 (refs 26-28). Tigers were recognized from their stripe patterns on the flanks, limbs and forequarter ${ }^{29}$, and we identified the sex after carefully observing the secondary sexual traits (i.e. genital portion) in the photo groups. We identified the ranges of individual female tigers from this database, which allowed us to collect information about the reproductive parameters of 15 breeding female tigers (i.e. litter size, inter-birth interval ${ }^{27}$; and minimum distribution (viz. home range area) of each female.

We also examined the dataset (i.e. photographs) of individual tigers collected from the authorities and tourist guides who regularly (twice/day) visited the Reserve. The scanty vegetation and road network in RTR provided ideal conditions for tiger sightings. Females are philopatric and likely remain in the same area for their entire life, while males often disperse from their natal ranges ${ }^{7}$. We used this information to reconstruct life histories of individual tigers in RTR. Since these data were gathered from multiple sources, the identity of individual tigers was also confirmed through our photographic dataset of tigers using their unique coat patterns ${ }^{30}$.

\section{Minimum distribution area and vacant home range analysis}

We used intensive camera trapping and direct observation of tigers to obtain a minimum distribution area (MDA) used by each animal. We defined resident tigers that resided in a centralized area for $\geq 8$ months, which is the minimum time necessary to estimate home-range size ${ }^{31}$. For residents, we generally estimated MDA prior to death, and for replacements we generally estimated home range area for the first 12 months that we documented the individual using the area. The MDA by each adult tiger was calculated using the $100 \%$ minimum convex polygon (MCP) using the software package Home Range Extension in ArcView 3.3 (ref. 32). We used MCP over kernel methods because of small sample size. Also, kernel methods require more even distribution of the locations to maintain accuracy ${ }^{33,34}$. We knew the age of females monitored during the study period, viz. 2005-11. For more details refer to Singh et al. ${ }^{28,35}$.

\section{Results and discussion}

During the study period, nine home ranges were vacated (two males and seven females) due to death, translocation or emigration of tigers ${ }^{13}$. The seven resident adult female tigers vacated their home ranges because of death $(n=3)$, translocation $(n=2)$ and emigration $(n=2)$. We documented mothers and related offspring of each sub-adult female born during the study (Table 1$)^{27}$. The sub-adult female (TF-41; TF is tiger female) at 28 months acquired 
RESEARCH ARTICLES

Table 1. Detail of home range vacated and acquired by tigers in Ranthambhore Tiger Reserve, India, April 2005 - June 2011

\begin{tabular}{|c|c|c|c|c|c|c|c|}
\hline $\begin{array}{l}\text { Resident } \\
\text { individual } \\
\text { identification } \\
\text { number }\end{array}$ & $\begin{array}{c}\text { Date of } \\
\text { vacated } \\
\text { home range }\end{array}$ & $\begin{array}{l}\text { Photo } \\
\text { captures }\end{array}$ & $\begin{array}{l}\text { Replacement } \\
\text { individual }\end{array}$ & $\begin{array}{c}\text { Date of first } \\
\text { photo-capture } \\
\text { in vacant } \\
\text { home range }\end{array}$ & $\begin{array}{l}\text { Photo captures } \\
\text { after acquisition } \\
\text { of home range }\end{array}$ & Relationship & $\begin{array}{l}\text { Cause of vacant home } \\
\text { range of resident tiger }\end{array}$ \\
\hline \multicolumn{8}{|l|}{ Female } \\
\hline $\mathrm{TF}-01$ & July 2008 & 19 & TF-19 & November 2008 & 34 & $\begin{array}{l}\text { Elder sister } \\
\text { (previous litter) }\end{array}$ & Translocation to $\mathrm{STR}^{28}$ \\
\hline TF-04 & April 2009 & 51 & TF-41 & May 2010 & 21 & Daughter & Died defending cubs ${ }^{36}$ \\
\hline TF-27 & January 2010 & 25 & & & & NA & Old age emigration \\
\hline TF-14 & October 2008 & 7 & TF-13 & November 2008 & 42 & Daughter & Died natural \\
\hline $\mathrm{TF}-15$ & September 2008 & 15 & TF-18 & October 2008 & 6 & NA & Died diseased $^{37}$ \\
\hline TF-13 & October 2010 & 75 & TF-39 & November 2010 & 15 & Daughter & $\begin{array}{l}\text { Emigration to avoid } \\
\text { infanticide }^{36}\end{array}$ \\
\hline $\mathrm{TF}-18$ & February 2009 & 6 & $\mathrm{TF}-22$ & February 2009 & 46 & NA & Translocation to $\mathrm{STR}^{28}$ \\
\hline \multicolumn{8}{|l|}{ Male } \\
\hline TM-12 & July 2010 & 80 & TF-24 & December 2010 & 21 & NA & Transient \\
\hline \multirow[t]{4}{*}{ TM-02 } & December 2008 & 61 & TM-03 & December 2008 & 90 & NA & Transient \\
\hline & & & TM-21 & February 2008 & 20 & NA & Transient \\
\hline & & & TM-28 & December 2008 & 96 & NA & Transient \\
\hline & & & TN-29 & December 2008 & 66 & NA & Transient \\
\hline
\end{tabular}

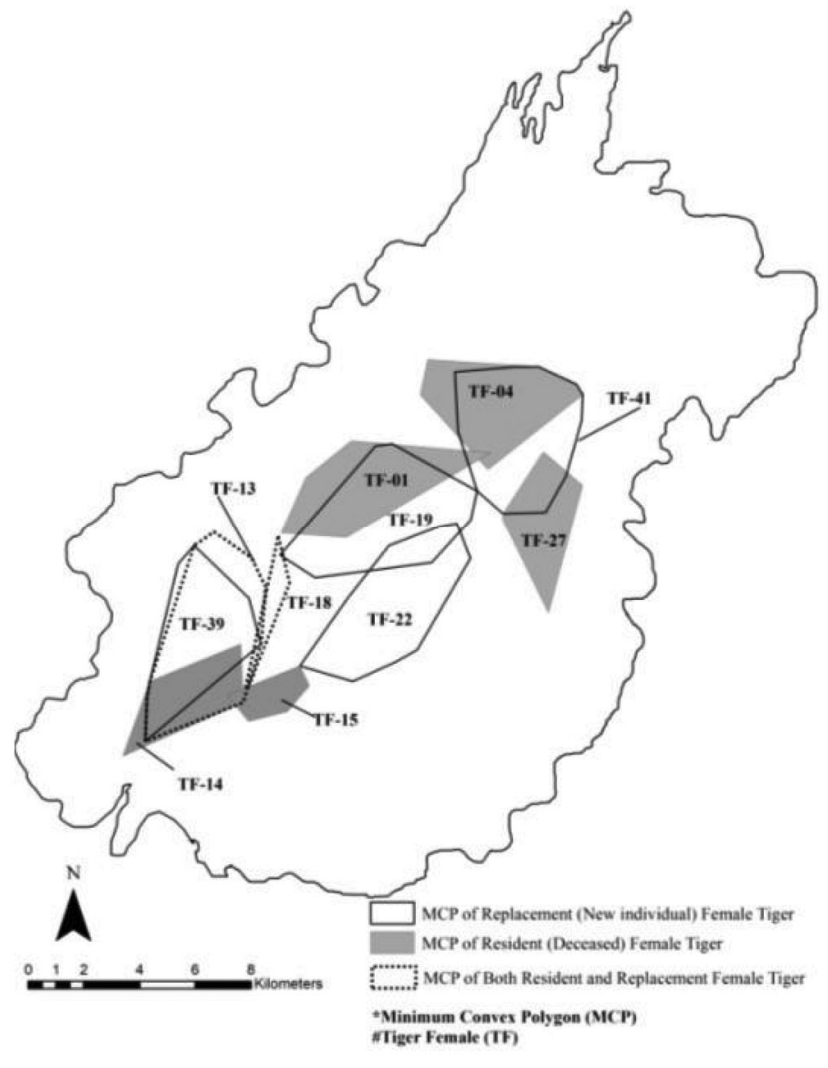

Figure 2. The distribution area of resident (tiger that vacated the home range) and replacement (tiger that replaced the one that vacated) female tigers using $100 \%$ minimum convex polygon (MCP), Ranthambhore Tiger Reserve, India, 2005-11.

the entire home range of two adult females (age $>72$ months) after the death of her mother (TF-04) in April 2009 and a home range vacated by an adult female (TF-27) due to old age emigration (Figure 2). Another sub-adult female (TF-19; 20 months) acquired the home range of the resident adult female (TF-01); this home range was vacated after her translocation to Sariska Tiger Reserve (STR) in July 2008. Both females were related (sisters). Female TF-13 took over the entire natal home range following the disappearance of her mother TF-14 (Figure 2). The female TF-13 left her natal home range in December 2010 to avoid infanticide ${ }^{36}$ and the home range was acquired by her daughter (TF-39). Similarly in another case after the death of the resident adult female (TF-15) in September 2008 (ref. 37), the vacated home range was occupied by a neighbouring dispersed sub-adult female (TF-18) and after the translocation of TF-18 in February 2009 to STR. Both females were not related to each other (Figure 2). Most $(n=4,57 \%)$ vacated home ranges were filled by neighbouring females. In two other cases, the mothers (TF-9 and TF-16) shifted their home ranges to share with their daughters (TF-11, TF-17 and TF-19; Figure 3). All the daughters gave birth to litters following the division of the maternal home ranges.

Two home ranges were vacated by resident adult male tigers because of death and translocation ${ }^{13}$. The adult male TM-12 ( $\geq 6$ years; TM is tiger male) was translocated to STR and his vacated home range was filled by a neighbouring adult male TM-24 ( $\geq 4$ years) living in the proximate habitat. This male tiger had been previously physically captured approximately $4 \mathrm{~km}$ away in a suboptimal habitat ${ }^{36}$. The home range area occupied by TM-02 during 2005 to 2010 was approximately 73 sq. km, but after the death of this tiger ( $\geq 9$ years), his vacated home ranges were taken over by four transient males (TM-03, TM-21, TM-28 and TM-29), which dispersed from different areas (Figure 4). 


\section{RESEARCH ARTICLES}

The literature suggests that female carnivores often settle in their natal areas and the mothers assist to increase the reproductive success of their daughters ${ }^{8}$. In this study we observed that the vacant home ranges after the occupants left were filled by neighbouring females for female residents and by transient individuals for male tigers. Similar observations have been documented in tigers by other researchers in India, Nepal and Russian Far East $^{31,38,39}$. In the degraded habitats carnivore territories remain vacated until habitat conditions not recovered, but with habitat impoverishment the area were gradually occupied by nearby individuals reported in Simlipal Tiger Reserve $^{40}$. Smith et al. ${ }^{38}$ documented the inheritance of maternal home ranges in Chitwan National Park, Nepal, because the mothers shared their home ranges with their daughters, while three other young females acquired similar home ranges after the death of the former residents. Similarly, in Amur tigers in the Russian Far East, two mothers shared their home ranges with their daughters and in two other cases, the females took over the entire natal home range following the disappearance of their mothers ${ }^{31}$. Laing and Lindzey ${ }^{42}$ reported that after the death of the resident mountain lions (Puma concolor), the vacant home ranges were occupied by individuals of the same sex. In swift foxes (Vulpes velox) after the disappearance of resident individuals, the vacant areas were re-occupied by new individuals ${ }^{42}$. Sandell ${ }^{43}$ suggested that in the most solitary carnivores, the spatial organization of females depends on the distribution of resources so that the neighbouring females are aware of the availability of resources in the adjacent home ranges to maximize their foraging and reproductive efficiency.

Researchers of large carnivores suggest that the home-range expansions or shifts to fill vacancies are common $^{10,12}$. We observed that younger tigers replaced vacancies in home ranges occupied by an old male tiger (TM-02). The age of TM-02 was assessed based on photo-capture records from the Forest Departments. This tiger was first photo-captured using camera traps in 1998 (ref. 30), when he was a sub-adult approximately 2 years old and the approximate age of TM- 02 was 12 years in 2008. The large home range of this tiger during 2005 to 2008 is because of the available space for male tigers, as there were only two adult tigers (TM-02 and TM-20) in 2006, which were photo-captured using camera trap, and the tiger habitat ( $344 \mathrm{sq} . \mathrm{km}$ ) was occupied by both male tigers. From 2008 onwards when dispersal started, the young transient males compelled the older tiger to restrict its distribution area in the fringes of the park. Hence our data are consistent with other studies.

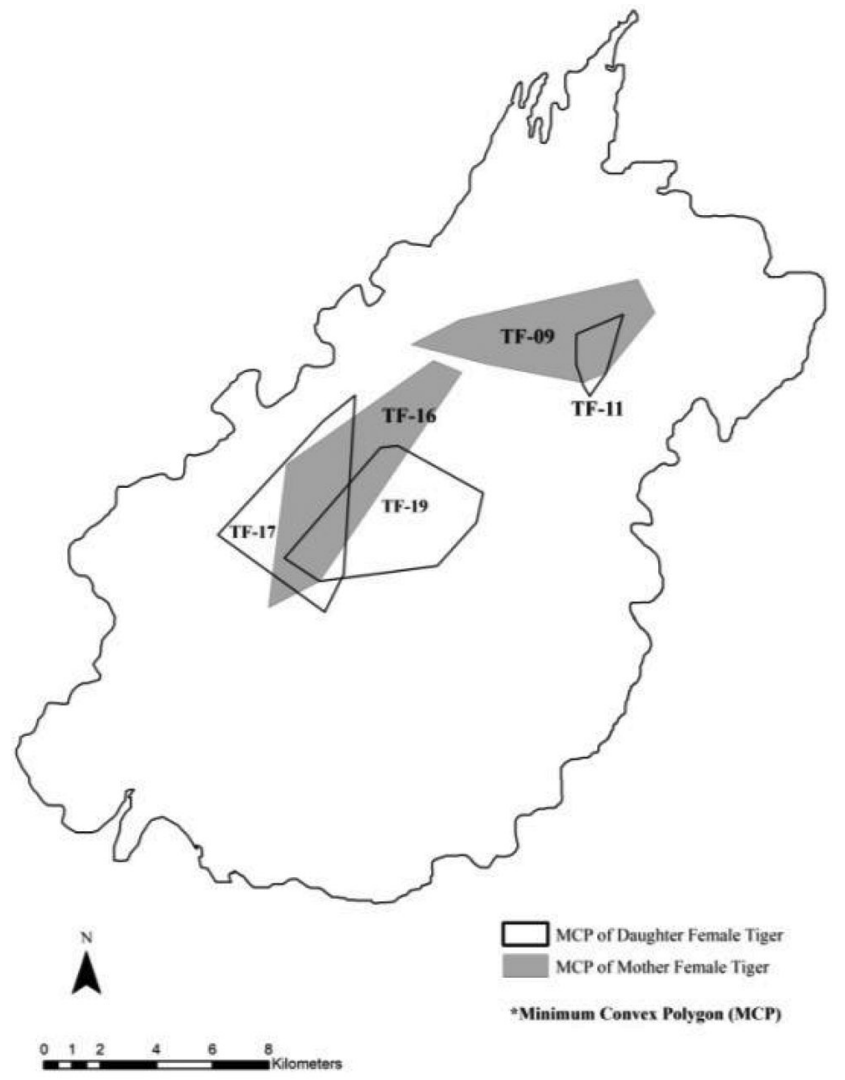

Figure 3. The distribution area of female mothers and with daughters using $100 \%$ minimum convex polygon (MCP), Ranthambhore Tiger Reserve, India, 2005-11.

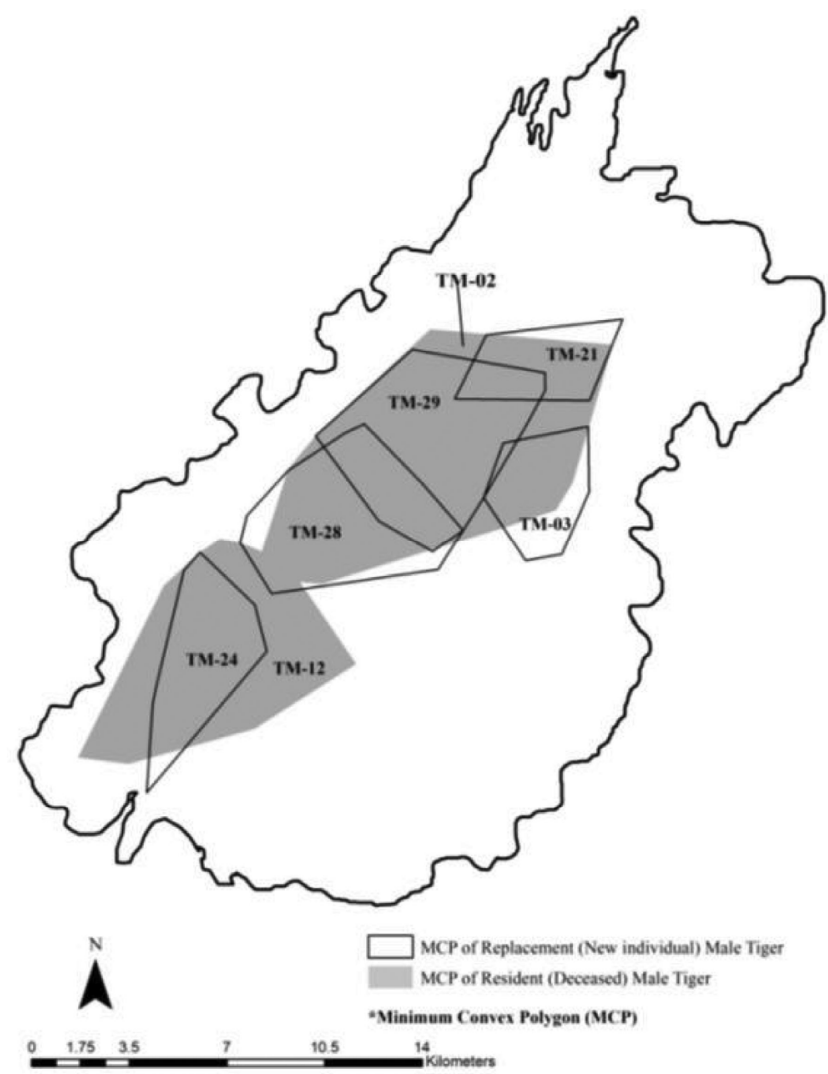

Figure 4. The distribution of resident (tiger that vacated the area) and replaced male tigers using 100\% minimum convex polygon (MCP), Ranthambhore Tiger Reserve, India, 2005-11. 
The vacant home range of RTR was due to decline of the tiger population in 2005 (ref. 44). Subsequently, after increased protection, the tiger numbers increased from 19 individuals in 2005 (ref. 26), to 36 individuals in 2010 and 45 individuals in 2014 (ref. 45). However the natural and anthropogenic mortality rate of tigers in RTR was 2.4 animals/year (ref. 13). Tigers in RTR have been reported to disperse to nearby areas, including protected areas through 'ridge top' narrow stepping stone connectivity'. Reddy et $a l .{ }^{46}$ reported evidence for movement of tigers to adjoining habitats in Madhya Pradesh across River Chambal. Mallick ${ }^{47}$ reported that during the recovery phase, tigers populations had expanded their distribution ranges in nearby areas, and for the long-term conservation of tigers it is necessary to maintain the forest corridors to ensure the exchange of genes from adjacent areas ${ }^{48}$. Such events may result in vacant home ranges and subsequently these would be filled by the nearby individuals. Thus this study will be useful to enhance our understanding about land tenure social organization and acquisition of vacant home ranges by tigers. It can also be used as baseline information for comparison in the future as part of management and conservation in $\mathrm{RTR}^{49}$.

Conflict of interest: The authors declare no conflict of interest.

1. Greenwood, P. J. and Harvey, P. H., The natal and breeding dispersal of birds. Annu. Rev. Ecol. Syst., 1982, 13, 1-21.

2. Stacey, P. B., Female promiscuity and male reproductive success in social birds and mammals. Am. Nat., 1982, 120, 51-64.

3. Lovallo, M. J. and Anderson, E. M., Range shift by a female bobcat (Lynx rufus) after removal of neighboring female. Am. Midl. Nat., 1995, 134(2), 409-412.

4. Greenwood, P. J., Mating systems, philopatry and dispersal in birds and mammals. Anim. Behav., 1980, 28, 1140-1162.

5. Sunquist, M. E., The social organization of tigers (Panthera tigris) in Royal Chitawan National Park, Smithsonian Contribution to Zoology, Nepal, 1981, 336, 1-98.

6. Goodrich, J. et al., Panthera tigris. In The IUCN Red list of Threatened Species, 2015; p. e. T15955A50659951. http://dx.doi. org/10.2305/IUCN.UK.2015-2.RLTS.T15955A50659951.en

7. Smith, J. L. D., Dispersal, communication, and conservation strategies for the tiger (Panthera tigris) in Royal Chitwan National Park, Nepal, University of Minnesota, USA, 1984.

8. Smith, J. L. D., The role of dispersal in structuring the Chitwan tiger population. Behaviour, 1993, 124, 165-195.

9. Singh, R., Qureshi, Q., Sankar, K., Krausman, P. R. and Goyal, S. P., Use of camera traps to determine dispersal of tigers in semiarid landscape, western India. J. Arid Environ., 2013, 98, 105-108.

10. Seidensticker, J. C., Hornocker, M. G., Wiles, W. V. and Messick, J. P., Mountain lion social organization in the Idaho primitive area. Wildl. Monogr., 1973, 35, 1-60.

11. Gaona, P., Ferreras, P. and Delibes, M., Dynamics and viability of a metapopulation of the endangered Iberian lynx (Lynx pardinus). Ecol. Monogr., 1998, 68, 349-370.

12. McDougal, C., The Face of the Tiger, Rivington Books, Distributed by Deutsch, 1977.

13. Singh, R., Krausman, P. R., Goyal, S. P. and Chauhan, N. S., Factors contributing to tiger losses in Ranthambhore Tiger Reserve, India. Wildl. Soc. Bull., 2015, 39, 670-673.
14. Pusey, A. E. and Packer, C., Infanticide in lions: consequences and counterstrategies. In Infanticide Parental Care (eds Parmigiani, S. and vom Saal, F.), Harwood Academic Publ., London, 1994, pp. $277-299$.

15. Swenson, J. E., Sandegren, F., Brunberg, S., Segerström, P. and Segerstrøm, P., Factors associated with loss of brown bear cubs in Sweden. Ursus, 2001, 12, 69-80.

16. Azevedo, F. C., Costa, R. L., Concone, H. V., Pires-da Silva, A. and Verdade, L. M., Cannibalism among jaguars (Panthera onca). Southwest. Nat., 2010, 55(4), 597-599.

17. Bailey, T. N., Social organization in a bobcat population. J. Wildlife Manage., 1974, 38(3), 435-446.

18. Aronsson, M. and Persson, J., Female breeding dispersal in wolverines, a solitary carnivore with high territorial fidelity. Eur. J. Wildl. Res., 2018, 64, 7.

19. Sunquist, M. and Sunquist, F., Wild Cats of the World, University of Chicago Press, Chicago, USA, 2002.

20. Sutherland, G. D., Harestad, A. S., Price, K. and Lertzman, K. P., Scaling of natal dispersal distances in terrestrial birds and mammals. Conserv. Ecol., 2000, 4, 16.

21. Elbroch, L. M. and Quigley, H., Social interactions in a solitary carnivore. Curr. Zool., 2016, 63, 357-362.

22. Jhala, Y., Gopal, R. and Qureshi, Q., Status of tigers, co-predators, and prey in India, National Tiger Conservation Authority, New Delhi and Wildlife Institute of India, 2008, TR 08/001, p. 151.

23. Jhala, Y., Qureshi, Q. and Gopal, R., Status of the tigers co-predators and prey in India (No. Tr 2011/003), National Tiger Conservation Authority, New Delhi and Wildlife Institute of India, Dehradun, 2010.

24. Singh, R., Qureshi, Q., Sankar, K., Krausman, P. R. and Goyal, S. P., Evaluating heterogeneity of sex-specific capture probability and precision in camera-trap population estimates of tigers. Wildl. Soc. Bull., 2014, 38, 791-796.

25. Champion, S. H. and Seth, S. K., A revised survey of the forest types of India. Govt of India Press, New Delhi, 1968, p. 404.

26. Chauhan, D., Harihar, A., Goyal, S., Qureshi, Q., Lal, P. and Mathur, V., Estimating tiger population using camera traps in Ranthambore National Park. Wildlife Institute of India, Dehradun, 2005, 24.

27. Singh, R., Majumder, A., Sankar, K., Qureshi, Q., Goyal, S. P. and Nigam, P., Interbirth interval and litter size of free-ranging Bengal tiger (Panthera tigris tigris) in dry tropical deciduous forests of India. Eur. J. Wildl. Res., 2013, 59, 629-636.

28. Singh, R., Krausman, P. R., Pandey, P., Qureshi, Q., Sankar, K., Goyal, S. P. and Tripathi, A., First parturition of tigers in a semiarid habitat, western India. Eur. J. Wildl. Res., 2014, 60, 383-386.

29. Majumder, A., Qureshi, Q., Sankar, K. and Kumar, A., Long-term monitoring of a Bengal tiger (Panthera tigris tigris) population in a human-dominated landscape of Central India. Eur. J. Wildl. Res., 2017, 63, 17 .

30. Karanth, K. U. and Nichols, J. D., Estimation of tiger densities in India using photographic captures and recaptures. Ecology, 1998, 79, 2852-2862.

31. Goodrich, J. M., Miquelle, D. G., Smirnov, E. N., Kerley, L. L., Quigley, H. B. and Hornocker, M. G., Spatial structure of Amur (Siberian) tigers (Panthera tigris altaica) on Sikhote-Alin Biosphere Zapovednik, Russia. J. Mammal., 2010, 91, 737-748.

32. Mohr, C. O., Table of equivalent populations of North American small mammals. Am. Midl. Nat., 1947, 37, 223-249.

33. Swihart, R. K. and Slade, N. A., Influence of sampling interval on estimates of home-range size. J. Wildl. Manage., 1985, 49(4), 1019-1025.

34. Seaman, D. E. and Powell, R. A., An evaluation of the accuracy of kernel density estimators for home range analysis. Ecology, 1996, 77, 2075-2085.

35. Singh, R., Qureshi, Q., Sankar, K., Krausman, P. R. and Goyal, S. P., Reproductive characteristics of female Bengal tigers in 
Ranthambhore Tiger Reserve, India. Eur. J. Wildl. Res., 2014, 60, 579-587.

36. Singh, R., Nigam, P., Qureshi, Q., Sankar, K., Krausman, P. R. and Goyal, S. P., Strategy of female tigers to avoid infanticide. Curr. Sci., 2014, 107(9), 1595-1597.

37. Singh, R., Nigam, P., Goyal, S. P., Joshi, B. D., Sharma, S. and Shekhawat, R. S., Survival of dispersed orphaned cubs of tiger (Panthera tigris tigris) in fragmented habitat of Ranthambhore Tiger Reserve in India. Indian For., 2011, 137, 1171-1176.

38. Smith, J. L. D., McDougal, C. W. and Sunquist, M. E., Land tenure system in female tigers. In Tigers of the World: The Biology, Biopolitics, Management, and Conservation of an Endangered Species (eds Tilson, R. L. and Seal, U. S.), Noyes Publications, Park Ridge, New Jersey, USA, 1987, pp. 97-108.

39. Panwar, H., Population dynamics and land tenure of tigers in Kanha National Park. Indian For. (Spec. Issue), 1979, 18-36.

40. Singh, L. and Swain, D., The implications of increase in leopard numbers. Indian For., 2005, 131, 1383-1385.

41. Laing, S. P. and Lindzey, F. G., Patterns of replacement of resident cougars in Southern Utah. J. Mammal., 1993, 74, 1056-1058.

42. Harrison, R. L., Swift fox demography, movements, denning, and diet in New Mexico. Southwest. Nat., 2003, 48, 261-274.

43. Sandell, M., The mating tactics and spacing patterns of solitary carnivores. In Carnivore Behavior, Ecology and Evolution (ed. Gittleman, J. L.), Cornell University Press, Ithaca, New York, USA, 1989, pp. 164-182.

44. Sharma, S. and Wright, B., Monitoring tigers in Ranthambore using the digital pugmark technique. Wildlife Protection Society of India, 2005.
45. Jhala, Y., Qureshi, Q. and Gopal, R., The status of tigers in India 2014. National Tiger Conservation Authority, New Delhi and Wildlife Institute of India, Dehradun, 2015, p. 28.

46. Reddy, P. A., Gour, D. S., Bhavanishankar, M., Jaggi, K., Hussain, S. M., Harika, K. and Shivaji, S., Genetic evidence of tiger population structure and migration within an isolated and fragmented landscape in northwest India. PLoS ONE, 2012, 7, e29827.

47. Mallick, J. K., Past and present status of the Indian tiger in northern west Bengal, India: an overview. J. Threat. Taxa, 2010, 2, 739-752.

48. Singh, L., Born black: the melanistic tiger in India. World Wide Fund for Nature-India, 1999.

49. Mathur, V. B., Gopal, R., Yadav, S. P., Negi, H. S. and Ansari, N. A., Management effectiveness evaluation (MEE) of Tiger Reserves in India: process and outcomes. National Tiger Conservation Authority and Wildlife Institute of India, Dehradun, 2014, p. 144.

ACKNOWLEDGEMENTS. We thank the Director and Dean Wildlife Institute of India (WII), Dehradun for support. We also thank the Rajasthan Forest Department, and park officials and field staff at Ranthambhore Tiger Reserve for the necessary permissions and support; M. Singh and S. Sharma for help during fieldwork, and WII for providing financial support for this study.

Received 23 March 2020; revised accepted 23 August 2020

doi: $10.18520 / \mathrm{cs} / \mathrm{v} 119 / \mathrm{i} 9 / 1549-1554$ 